\title{
NOVICE COUNSELOR'S WORK READINESS
}

\section{Tri Sutanti*, Suharsimi Arikunto, Irvan Budhi Handaka \\ *Correspondent Author}

Tri Sutanti

Universitas Ahmad Dahlan

Jalan Ring Road Selatan Yogyakarta, Indonesia

Email: tri.sutanti@bk.uad.ac.id

Suharsimi Arikunto

Universitas Ahmad Dahlan

Jalan Ring Road Selatan Yogyakarta, Indonesia

Email: suharsimi.arikunta@bk.uad.ac.id

Irvan Budhi Handaka

Universitas Ahmad Dahlan

Jalan Ring Road Selatan Yogyakarta,

Indonesia

Email: irvan.handaka@bk.uad.ac.id

Page

17-22

\begin{abstract}
This descriptive study aims to find out the novice counselors' work readiness. To this end, fifty-four novice counselors graduated from the guidance and counseling department of Ahmad Dahlan University were recruited. The data were collected using a work readiness scale and analyzed using a quantitative descriptive technique. The result showed that the school counselors' strongest aspect lay in work attitude, while the weakest aspect lay in interpersonal communication. Based on the focus group discussion, novice counselors still faced some difficulties when providing guidance and counseling services at school. The most frequently found obstacles were their ability to deal with the students' mental, assertiveness, group counseling services, collaboration service, and service management. This study can be used as the basis to develop a service or training strategy to improve the novice counselors' work readiness.

Keywords: work readiness, novice counselor, interpersonal communication, work attitude.
\end{abstract}

\section{INTRODUCTION}

Globalization does influence the working world as it demands more competitive human resources in any sector. In this regard, one of the high education institution's responsibilities is to develop workforce competence. University graduates are expected to have adequate competence when entering the working world.

Failure to meet this demand is likely to result in unemployment. Unemployment in Indonesia is also experienced by university graduates, not only those with lower educational backgrounds. Agustiyani (2019) cites data issued by Statistics Indonesia that in August 2019, Unemployment in Indonesia increased from 7 million to 7.05 million. Of this considerable number, $5.67 \%$ of unemployed people were university graduates. High unemployment rate does not only lead to economic issues but also social issues such as poverty and social vulnerability.

Work readiness denotes one's ability to find a well-paying job and ability to develop in his/her job. Caballero (2011: 42) defines work readiness as the degree to which a graduate exhibits attitude and character that makes them ready to succeed in the work environment.

Bandaranaike and Willison's (2015) study on 138 students in the University of Adelaide and 111 entrepreneurs found that students 


\title{
18 | PSIKOPEDAGOGIA
}

\author{
JURNAL BIMBINGAN DAN KONSELING
}

Vol.10, No.1, June 2021

have a limited understanding of work readiness and affective skills. Their study also reveals that entrepreneurs emphasize the importance of higher affective skills in the work environment. Some students also have not understood the work readiness required by the work environment and the importance of higher effective skills.

The observation and interview with the guidance and counseling department head found that the department has made several efforts to develop its graduate's work readiness through practice-based learning to improve their guidance and counseling skills. Though the efforts focus on improving students' cognitive and affective skills, the average waiting time between graduation and employment of guidance and counseling department is two months and two days. In other words, graduates need to wait before they obtain their first employment indicating that the guidance and counseling department graduates need some improvement.

According to the national regulation of the ministry of education of the Republic of Indonesia no. 27 of 2008, school counselors should possess personality, social pedagogical, and professional competence. School counselors are required to help and support the students' character development through psycho-pedagogical guidance and counseling services. Working together with classroom teachers and school administrators, school counselors play pivotal roles in developing students' character. They need to understand how to be a professional counselor who serves as a model for their students, is sensitive and responsive to the students' problems, and is capable of providing effective guidance and counseling services to optimize students' development.

Nevertheless, school counselors are currently viewed as school police. Rahman, in his study (2010:4), found that most students view school counselors as scary school police. The guidance and counseling unit itself even turns into an administrative unit to discipline and punish students considered disobeying the school rules. This finding shows that school counselors are less responsive to students' problems and focus more on less-disciplined students.

These alarming findings indicate that counselors' functions should be thoroughly prepared since they are at the university level. Considering the importance of counselors' work readiness, this study aims to find out the work readiness among novice counselors who graduated from the guidance and counseling department of Universitas Ahmad Dahlan. This study can be used as the basis to develop a service or training strategy to improve novice counselor's readiness.

\section{RESEARCH METHOD}

This descriptive study aimed to find out the novice counselors' work readiness. To this end, fifty-four guidance and counseling graduates were recruited using the purposive sampling technique. A work readiness scale was distributed to collect the data. Focus Group Discussion on novice counselors' work readiness was also conducted. The collected data were analyzed using quantitative descriptive technique and Miles and Huberman's qualitative data analysis (in Sugiyono, 2017).

\section{RESULTS AND DISCUSSIONS}

\section{A. Novice Counselors' Work Readiness Before The Model Development}

The following figure presents the data analysis result on novice counselors' work readiness:

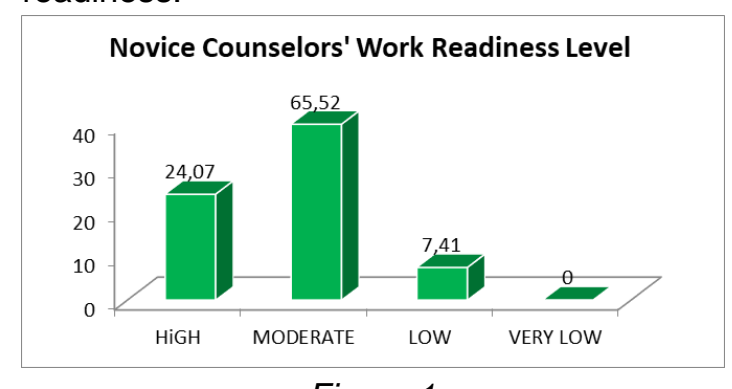

Figure 1

Novice Counselors' Work Readiness Level

As presented in the figure, most novice counselors' work readiness level (65.52\%) was categorized as moderate, $24.07 \%$ was categorized as high, while $7.41 \%$ was 
categorized as low. This result means that it is necesary to improve the novice counselors' work readiness.

Novice counselors' work readiness was also explored more closely by considering each aspect of the work readiness.

Table 1

Aspects of Work Readiness

\begin{tabular}{ll}
\hline Aspects of Work Readiness & Mean \\
\hline Motivation & 2.81 \\
Maturity & 3.17 \\
Personal Growth & 3.14 \\
Organizational Awareness & 3.00 \\
Technical focus & 2.94 \\
Interpersonal Communication Skill & 2.33 \\
Work Attitude & 3.39 \\
Problem-Solving & 2.84 \\
Adaptability & 3.13 \\
\hline
\end{tabular}

Having closer look to each aspect, as shown in the table above, the highest aspect score was found in work attitude (3.39), followed by maturity (3.17), whereas the lowest score was found in the interpersonal communication skill (2.33).

In terms of gender, data on novice counselors' work readiness were displayed in the following figure.

\section{Average Work Readiness in terms of Gender}

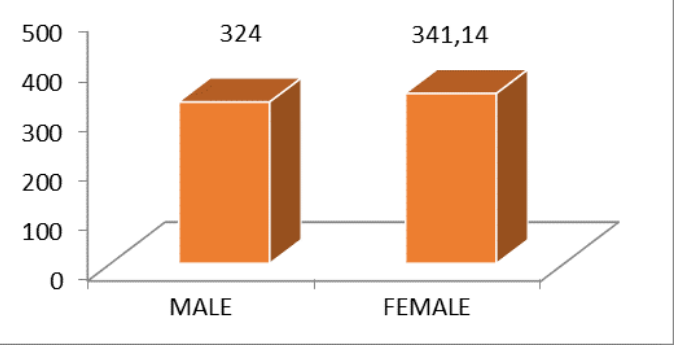

Figure 2

Work Readiness (Gender-Based)

In terms of gender, the analysis result show that female novice counselors' work readiness (341.14) was higher than male novice counselors' (324). However, both were categorized as moderate.
The following figure presents the novice counselors' work readiness in terms of job tenure.

\section{AVERAGE WORK READINESS IN TERMS OF JOB TENURE}

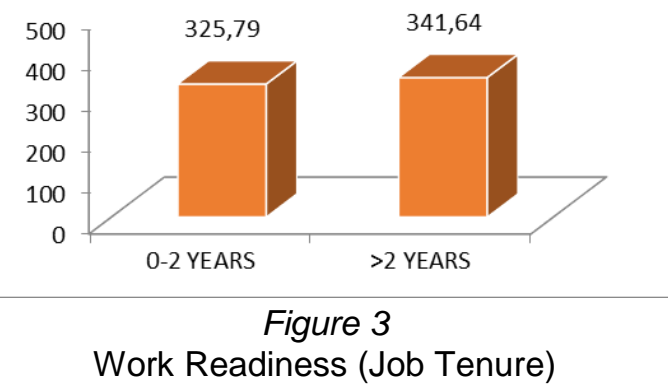

The data analysis result showed that novice counselors with job tenure more than two years was higher than those less than two years.

\section{B. Focus Group Discussion Result on Novice Counselors' Work Readiness}

A focus group discussion was also conducted to gain better depiction of novice counselors' work readiness. This discussion involved sixteen school counselors in Yogyakarta, recruited using purposive sampling technique. The discussion was held to obtain feedback and suggestions for the guidance and counseling department in optimizing its graduates' work readiness. In addition to focus group discussion, an openended questionnaire was also distributed. The participants' responses were grouped into five response categories, including: The most needed competence/skills by novice counselors, obstacles faced by novice counselors, challenges faced by novice counselors, courses important in work environment, most difficult guidance and counseling service to apply.

The following table presents the data on novice counselors' work readiness based on focus group discussion. 


\title{
20 | PSIKOPEDAGOGIA
}

\author{
JURNAL BIMBINGAN DAN KONSELING
}

Vol.10, No.1, June 2021

Table 2

Focus Group Discussion on Novice Counselors' Work Readiness

\begin{tabular}{|c|c|c|}
\hline Component & Category & Description \\
\hline \multirow[t]{4}{*}{ Competence } & Academic & $\begin{array}{l}\text { Mental Readiness in } \\
\text { encountering students } \\
\text { Personality and } \\
\text { adaptability } \\
\text { Guidance and } \\
\text { Counseling Management } \\
\text { Ability to understand } \\
\text { individuals } \\
\text { Counseling Skills }\end{array}$ \\
\hline & & Group counseling skills \\
\hline & & $\begin{array}{l}\text { Flexibility in applying } \\
\text { theories } \\
\text { Islamic Counseling skill }\end{array}$ \\
\hline & & English Language \\
\hline \multirow[t]{2}{*}{ Obstacle } & $\begin{array}{l}\text { Manageme } \\
\mathrm{nt}\end{array}$ & $\begin{array}{l}\text { Excessive guidance and } \\
\text { counseling } \\
\text { administration } \\
\text { Helping other teachers' } \\
\text { task / given non } \\
\text { guidance and counseling } \\
\text { tasks. } \\
\text { Having no classroom } \\
\text { hours and act like a } \\
\text { school police. }\end{array}$ \\
\hline & $\begin{array}{l}\text { Interperson } \\
\text { al }\end{array}$ & $\begin{array}{l}\text { Finding it difficult to } \\
\text { perform collaborative } \\
\text { service } \\
\text { Finding it difficult to } \\
\text { handle students from } \\
\text { different cultures (non- } \\
\text { javanese) } \\
\text { Lack of Confidence, } \\
\text { Anxiety, poor } \\
\text { adaptability }\end{array}$ \\
\hline \multirow[t]{2}{*}{ Challenge } & Technology & $\begin{array}{l}\text { Applying technology in } \\
\text { guidance and counseling } \\
\text { services }\end{array}$ \\
\hline & Innovation & $\begin{array}{l}\text { Guidance and } \\
\text { counseling service } \\
\text { innovation }\end{array}$ \\
\hline \multirow[t]{2}{*}{$\begin{array}{l}\text { Important } \\
\text { Course }\end{array}$} & Course & $\begin{array}{l}\text { Guidance and } \\
\text { Counseling Management } \\
\text { Case study }\end{array}$ \\
\hline & & $\begin{array}{l}\text { Guidance and } \\
\text { Counseling service } \\
\text { evaluation }\end{array}$ \\
\hline \multirow{3}{*}{$\begin{array}{l}\text { Most difficult } \\
\text { guidance and } \\
\text { counseling } \\
\text { services to } \\
\text { apply }\end{array}$} & Service & Group counseling \\
\hline & & Group guidance \\
\hline & & Career guidance \\
\hline
\end{tabular}

Several assumptions can be made based on the analysis result described above.

1. The majority of novice counselors' work readiness was categorized as moderate, while the highest and the lowest aspect was found in work attitude and interpersonal communication skill, respectively.
2. In terms of gender, female novice counselors' exhibited higher work readiness than male novice counselors.

3. The most important skills needed by novice counselors include mental readiness to face students, personality, and adaptability. Academic skills novice counselors find it important includes ability to understand individuals, counseling skill, group counseling skills, flexibility in applying theories, Islamic counseling skills, and English language skills.

4. Meanwhile, the obstacles faced by novice counselors include excessive administrative work, non-guidance and counseling tasks, having no classroom hours and act as school police instead, difficulty in performing collaborative service, difficulty in handling students from different cultural backgrounds (nonjavanese), lack of confidence, anxiety, and poor adaptability.

5. Challenges faced by novice counselors include technology mastery and innovation in guidance and counseling services.

6. The important course in the work environment include guidance and counseling management, individual understnding, case study, and service evaluation.

\section{Discussion}

Work readiness denotes one's ability to find a well-paying job and develop in his/her job. Caballero (2011) defines work readiness as the degree to which an individual is considered to have an attitude and character that make them ready to succeed in their work environment. Affective skills serve as an important aspect in the work environment (Carol, 2014; Kooij et al., 2018; Spreitzer et al., 2017; Benozzo \& Colley, 2012; Chin et al., 2011; Baranovich \& Leong, 2018).

Bandaranaike and Willison's (2015) study on 138 students in the University of Adelaide and 111 entrepreneurs found that students have limited work readiness and affective skills. Previous studies found that affective skills are more important than cognitive skills 
in the work environment (Jollands, Jolly, \& Molyneaux, 2012; Kwok, Gujral\& Chan,2014; Patterson, Boyd, \& Mnatzaganian, 2017). The result of this study is in line with those of previous studies, indicating that it is highly important to develop novice counselors' work readiness, particularly the aspect of interpersonal communication.

According to Harvey (as cited in Suniti, John Wilson (2015: 1), a job is not only related to finding it but to the development of one's attribute, technique, or life experience. Working is a complex phenomenon involving more than simply cognitive skill achievement. Graduates need to have social and emotional intelligence, in addition to cognitive skills. In other words, when individuals enter the work environment, they need to possess emotional, social, and cognitive skills. Novice counselors need to have work readiness to engage with the system, yet the result of the study showed that their collaboration management skills need to be improved. Technology mastery is an important aspect for the workforce in this globalization era. Studies have proven that lack of technological mastery hinders individuals from having a successful career (Kivunja, 2014; Singh, Mehra, 2013). The present study found that novice counselors' technological mastery needs an improvement. In addition, the FGD reveals that their poor technological mastery affects their confidence when providing services. This study found that novice counselors' work readiness was still low, particularly in the problem-solving aspect. Meanwhile, existing studies have proven that problem-solving skills are significantly important in determining one's success in the work environment (Abdul \& Islam, 2014; Kahirol, Nor, Mimi \& Lai,2017; Makki, Salleh, Memon \& Harun, 2015; Wye, Lim \& Lee, 2012).

\section{CONCLUSION}

This study concludes that most novice counselors' work readiness is categorized as moderate. Work attitude was found as the highest aspect possessed by the novice counselors' work attitude, while the lowest aspects were interpersonal communication, problem-solving skills, and technology mastery. This study found that novice counselors faced some obstacles when conducting guidance and counseling services. The most frequent issues were mentality in handling students, assertiveness in conducting group counseling, collaboration, and service management. Based on the finding, developing a training model to improve novice counselors' work readiness is necessary. This study provides Universitas Ahmad Dahlan with valuable information regarding its graduates' work readiness. In this regard, it is recommended to develop a training model to improve novice counselors' work readiness.

\section{REFERENCE}

Abdul Hamid, M.S. \& Islam, R. (2014). Employability Skills Development Approaches: An Application of The Analytic Network Process. Asian Academy of Management Journal, 19 (1), 93-111.

Bandaranaike, Suniti. John Willison (2015). Building Capacity For WorkReadiness: Bridging The Cognitive And Affective Domains. Asia-Pacific Journal of Cooperative Education, Special Issue, 2015, 16(3), 223-233.

Benozzo, A., \& Colley, H. (2012). Emotion and Learning In The Workplace: Critical Perspectives. Journal Of Workplace Learning.

Caballero, C., Walker, A., \& FullerTyszkiewicz, M. (2011). The Work Readiness Scale (WRS): Developing a measure to assess work readiness in college graduates. Journal of Teaching and Learning for Graduate Employability, 2(2), 41 - 54

Carol, A. (2014). Factors Influencing Work Readiness of Graduates: An Exploratory Study. Stellenbosch University.

Chin, S. T. S., Anantharaman, R. N., \& Tong, D. Y. K. (2011). The Roles Of Emotional Intelligence and Spiritual Intelligence at The Workplace. Journal of Human Resources Management Research, 1-9.

Jollands, M., Jolly, L., \& Molyneaux, T. (2012). Project-Based Learning As A Contributing Factor To Graduates' Work Readiness. European Journal 


\section{2। PSIKOPEDAGOGIA}

JURNAL BIMBINGAN DAN KONSELING

Vol.10, No.1, June 2021

of Engineering Education, 37(2), 143154.

Kahirol, M. S., Nor Lisa, S., Mimi, M. M. \& Lai, C. S. (2017). Assessing Soft Skills Components In Science And Technology Programs Within Malaysian Technical Universities. Songklanakarin J. Sci. Technol. 39 (3), 399-405.

Kivunja, C. (2014). Do You Want Your Students To Be Job-Ready With 21st Century Skills? Change Pedagogies: A Pedagogical Paradigm Shift From Vygotskyian Social Constructivism To Critical Thinking, Problem Solving And Siemens' Digital Connectivism. International Journal of Higher Education, 3(3), 81.

Kooij, D. T. A. M., Kanfer, R., Betts, M., \& Rudolph, C. W. (2018). Future Time Perspective: A Systematic Review And Meta-Analysis. Journal of Applied Psychology, 103(8), 867-893.

Kwok, D., Gujral, M., \& Chan, J. (2014). Work Readiness: A Study of Student Intern's Self-Perception and Supervisor Evaluation. In International Conference on Teaching \& Learning in Higher Education (pp. 2011-2013). Singapore.

Lau, Poh Li., Diana-Lea Baranovich \&Kwan $\mathrm{Eu}$ Leong. Enhancing Work Readiness. (2018). A Review Of Carer Addolescents In Malaysia. International Journal of Education, Psychology and Counseling, 3(8), 1320.

Makki, Bilal Iftikhar Rohani Salleh, Mumtaz Ali Memon and Haryanni Harun (2015). The Relationship Between Work Readiness Skills, Career Self-Efficacy And Career Exploration Among Engineering Graduates: A Proposed Framework. Research Journal of Applied Sciences, Engineering and Technology, 10(9), 1007-1011.

Patterson, E. E. B., Boyd, L., \& Mnatzaganian, G. (2017). The Impact Of Undergraduate Clinical Teaching Models On The Perceptions Of WorkReadiness Among New Graduate Nurses: A Cross Sectional Study. Nurse Education Today, 55, 101-106.

Permendiknas No 27 Tahun 2008 Standar Kualifikasi Akademik Konselor.

Rahman, Fathur. (2010). Revitalisasi Peran dan Fungsi Guru Bimbingan dan
Konseling Dalam Suasana

Pendidikan.

Spreitzer, G. M., Cameron, L., \& Garrett, L. (2017). Alternative Work Arrangements: Two Images Of The New World Of Work. Annual Review of Organizational Psychology and Organizational Behavior, 4, 473-499.

Sugiyono. (2017). Metode Penelitian Kuantitatif, Kualitatif, dan R\&D. Bandung: Alfabeta.

Vandana Singh and Bharat Mehra (2013). Strengths and Weaknesses of the Information Technology Curriculum in Library and Information Science Graduate Programs. Journal of Librarianship and Information Science, 45(2), 219-231.

Wye, C-K., Lim, Y-M \& Lee, T-H. (2012). Perceived Job Readiness of Business Students at The Institutes of Higher Learning in Malaysia. International Journal of Advances in Management and Economics. 1(6), 149-156.

Agustiani (2019). https://www.bps.go.id/ diakses 5 November 2019 pukul 20.15 WIB 